This article was downloaded by:[Columbia University HHMI]

On: 28 June 2008

Access Details: [subscription number 794096172]

Publisher: Informa Healthcare

Informa Ltd Registered in England and Wales Registered Number: 1072954

Registered office: Mortimer House, 37-41 Mortimer Street, London W1T 3JH, UK

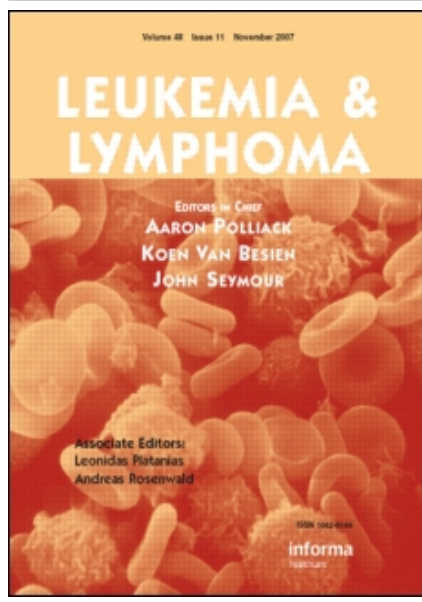

\title{
Leukemia and Lymphoma
}

Publication details, including instructions for authors and subscription information: http://www.informaworld.com/smpp/title content=t713643806 Chronic myeloid leukemia and HIV-infection

Robert Schlaberg ${ }^{a}$; Julie G. Fisher ${ }^{\text {b; }}$ Michael J. Flamm ${ }^{\text {b; Vundavalli V. Murty }}{ }^{a}$; Govind Bhagat ${ }^{a}$; Bachir Alobeid ${ }^{a}$

a Departments of Pathology,

b Medicine, Columbia University Medical Center, New York, NY, US

First Published: June 2008

To cite this Article: Schlaberg, Robert, Fisher, Julie G., Flamm, Michael J., Murty, Vundavalli V., Bhagat, Govind and Alobeid, Bachir (2008) 'Chronic myeloid leukemia and HIV-infection', Leukemia and Lymphoma, 49:6, 1155 - 1160

To link to this article: DOI: $10.1080 / 10428190802074601$

URL: http://dx.doi.org/10.1080/10428190802074601

\section{PLEASE SCROLL DOWN FOR ARTICLE}

Full terms and conditions of use: http://www.informaworld.com/terms-and-conditions-of-access.pdf

This article maybe used for research, teaching and private study purposes. Any substantial or systematic reproduction, re-distribution, re-selling, loan or sub-licensing, systematic supply or distribution in any form to anyone is expressly forbidden.

The publisher does not give any warranty express or implied or make any representation that the contents will be complete or accurate or up to date. The accuracy of any instructions, formulae and drug doses should be independently verified with primary sources. The publisher shall not be liable for any loss, actions, claims, proceedings, demand or costs or damages whatsoever or howsoever caused arising directly or indirectly in connection with or arising out of the use of this material. 
Leukemia E Lymphoma, June 2008; 49(6): 1155-1160

informa

ORIGINAL ARTICLE: CLINICAL

\title{
Chronic myeloid leukemia and HIV-infection
}

\author{
ROBERT SCHLABERG ${ }^{1}$, JULIE G. FISHER ${ }^{2}$, MICHAEL J. FLAMM ${ }^{2}$, \\ VUNDAVALLI V. MURTY ${ }^{1}$, GOVIND BHAGAT ${ }^{1}$, \& BACHIR ALOBEID ${ }^{1}$ \\ Departments of Pathology ${ }^{1}$ and Medicine ${ }^{2}$, Columbia University Medical Center, New York, NY, US
}

(Received 1 February 2008; revised and accepted 23 March 2008)

\begin{abstract}
The incidence of non-HIV-associated hematologic malignancies, including chronic myeloproliferative disorders, is increasing in HIV-infected (HIV+) patients. This is thought to be due to prolonged survival in the era of highly active antiretroviral therapy (HAART). Previously, only six cases of chronic myeloid leukemia (CML) have been described in $\mathrm{HIV}+$ individuals and limited information is available regarding the management of patients with concurrent CML and HIVinfection. We report three cases of CML in HIV+ patients who were treated with imatinib and HAART. Treatment was generally well tolerated, and cytogenetic response (complete in two patients) was achieved with follow-up ranging from 3 to 69 months. HIV viral load remained undetectable and CD4 cell counts were stable in all three patients. Concurrent treatment with imatinib and HAART can result in appropriate control of CML and HIV-infection as well as long-term survival.
\end{abstract}

Keywords: Chronic myeloid leukemia, HIV, AIDS, imatinib, HAART

\section{Introduction}

Human immunodeficiency virus-infected (HIV+) individuals are at high risk for developing neoplasms. Malignancies are responsible for $25-30 \%$ of all deaths in patients treated with highly active antiretroviral therapy (HAART) $[1,2]$, as compared with only $10 \%$ in the pre-HAART era $[3,4]$. The increased malignancy-related mortality is most likely a result of decreasing opportunistic infections, prolonged survival and development of age-related neoplasms [2,5-7].

Hodgkin lymphoma and multiple myeloma are the most frequently reported non-AIDS-defining hematologic malignancies in HIV-infected individuals [2]. Sporadic cases of chronic myeloproliferative disorders (CMPD), such as polycythemia vera, hypereosinophilic syndrome and mast cell disorders have also been reported [8-16]. To this date, six cases of chronic myeloid leukemia (CML) have been described in HIV+ individuals, only two of which were treated with current regimens [17]. One patient was concurrently treated with imatinib and HAART, and the other patient received an allogeneic bone marrow transplant in combination with HAART. Experience regarding the treatment of CML in HIV+ individuals is limited and several considerations warrant special attention: both conditions as well as their respective therapies may cause bone marrow failure and pharmacological interactions between HAART and imatinib may require adjustment of therapy.

We report on three HIV+ patients diagnosed with CML in our institution. All three patients were successfully treated with HAART and imatinib and have sustained cytogenetic remission (complete in two) during a follow-up period ranging from 3 to 69 months.

\section{Methods and patients}

Morphology

Hematoxylin and eosin stained sections of decalcified, Bouins-fixed, paraffin-embedded bone marrow

Correspondence: Bachir Alobeid, Department of Pathology, Columbia University Medical Center, 14-229 Vanderbilt Clinic, 630 West 168th St., New York, NY 10032, USA. Tel: +212-342-0545. Fax: +212-305-2301. E-mail: ba2024@columbia.edu 
core biopsies, Giemsa-stained, air-dried bone marrow aspirate smears and Wright-stained, air-dried peripheral blood smears were reviewed.

\section{Immunohistochemistry}

Immunohistochemical staining was performed on paraffin-embedded tissue sections with primary antibodies directed against CD34, CD117, MPO, Glycophorin A and CD61 using standard methods.

\section{Flow cytometry}

Three or four-colour flow cytometric analysis (FACScan; Becton Dickinson, San Diego, CA) was performed on peripheral blood and bone marrow aspirate samples using standard procedures and data were analysed using the Cell Quest software (Becton Dickinson). Lymphoid (T-, B-, NK-cell) and myeloid/monocytic lineage specific/associated antigens were analysed using a comprehensive panel of monoclonal antibodies.

\section{Cytogenetics}

Giemsa banded karyotype analysis was performed on metaphase preparations from overnight cell cultures without mitogen stimulation using standard methods. Karyotypes were described according to ISCN 2005 [18]. Fluorescence in situ hybridisation (FISH) analysis was performed on standard chromosome preparations using $B C R / A B L$ Dual Color, Dual Fusion Translocation Probe (Abbott Molecular, Des Plaines, IL) and standard protocols. Quantitative FISH analyses and follow-up examinations were performed on 500 interphase nuclei.

\section{Patient 1}

A 62-year-old Caucasian male with a 16-year history of HIV-infection, recurrent thrush and abdominal DLBCL was incidentally found to have leukocytosis (44,700/ $\mu \mathrm{L}$, reference range: $3500-9100)$ and mild macrocytic/hypochromic anemia ( $\mathrm{Hb} 12.6 \mathrm{~g} / \mathrm{dL}$, reference range: $13.3-16.2$; MCV $101.8 \mathrm{fl}$, reference range: 79.0-93.3; MCHC $31.4 \mathrm{~g} / \mathrm{dL}$, reference range: 32.3-35.9). The patient had received HAART for the past 3 years (most recently nevirapine, abacavir/lamivudine/zidovudine) and had achieved complete virological $(<50$ copies/ $\mathrm{mL}$ ) and immunologic (CD4 cell count $488 / \mu \mathrm{L}$, reference range: 393-1489) response. His past medical history was significant for DLBCL diagnosed 22-months prior. Treatment with 6 cycles of R-CHOP had been completed over the ensuing 14 months.
At presentation, a differential count showed 57\% neutrophils, $6 \%$ basophils, $1 \%$ metamyelocytes, $2 \%$ myelocytes, $5 \%$ atypical lymphocytes and $0.5 \%$ nucleated RBC. Serum chemistry evaluation was significant only for a mildly increased creatinine of $1.9 \mathrm{mg} / \mathrm{dL}$ (reference range: 0.6-1.2).

Bone marrow examination showed hypercellularity $(>95 \%)$ due to marked myeloid and megakaryocytic hyperplasia, without increase in blasts. Karyotypic analysis revealed a $\mathrm{t}(9 ; 22)(\mathrm{q} 34 ; \mathrm{q} 11.2)$ translocation in 20 out of 20 metaphases (Figure 1). FISH analysis using $B C R / A B L$ dual fusion probes showed a nuclear fusion signal in $93.3 \%$ of interphase nuclei (Figure 1). The diagnosis of chronic phase CML was established, the prognostic Sokal index was 1.08 (intermediate-risk), and the Hasford score was 1211.9 (intermediate-risk). Treatment with $600 \mathrm{mg}$ imatinib daily was initiated, which the patient tolerated without any side effects or complications. Hematologic remission with persistent mild thrombocytopenia $\left(115 \times 10^{9} / \mathrm{L}\right)$ was achieved within 6 weeks of diagnosis. Cytogenetic follow-up, 3 months after initial diagnosis, revealed a minor cytogenetic response $(74 \% \mathrm{Ph}+$ cells in peripheral blood). A $\mathrm{CBC}$ at this time demonstrated hematologic remission with a WBC of $4 \times 10^{9} / \mathrm{L}, \mathrm{Hb}$ of $11.4 \mathrm{~g} / \mathrm{dL}$ and platelet count of $129 \times 10^{9} / \mathrm{L}$.

No further cytogenetic follow-up was available. Mean WBC, $\mathrm{Hb}$ and platelet counts during 19 months of follow-up were $4.7 \times 10^{9} / \mathrm{L}, 13.3 \mathrm{~g} / \mathrm{dL}$ and $142 \times 10^{9} / \mathrm{L}$, respectively. The patient's viral load remained undetectable $(<50$ copies $/ \mathrm{mL})$, and the most recent CD 4 cell count was 488 cells $/ \mu \mathrm{L}$.

\section{Patient 2}

A 57-year-old African American male with a 17-year history of HIV-infection previously complicated by oral thrush and Pneumocystis carinii (jiroveci) pneumonia presented with vomiting, diarrhea and $7.5 \mathrm{~kg}$ weight loss over 3 months. The patient had received HAART for the past 3 years (lopinavir/ritonavir, abacavir/lamivudine/zidovudine), which resulted in complete virological $(<50$ copies $/ \mathrm{mL}$ ) and immunologic (CD4 count of $508 / \mu \mathrm{L})$ response. He had been diagnosed with squamous cell carcinoma of the larynx 5 years prior (treated with total laryngectomy and radiation therapy), chronic hepatitis $\mathrm{C}$ virus infection 6 years prior, coronary artery disease, diabetes mellitus and hypertension.

At presentation, he had mild hepatomegaly and leukocytosis $(48,000 / \mu \mathrm{L})$ with $40 \%$ neutrophils, $8 \%$ basophils, $5 \%$ metamyelocytes, $13 \%$ myelocytes, $5 \%$ promyelocytes, $9 \%$ myeloblasts and 5\% nucleated RBC, macrocytic normochromic anemia (Hb $9.4 \mathrm{~g} / \mathrm{dL}, \mathrm{MCV} 108.6 \mathrm{fl}, \mathrm{MCHC} 32.5 \mathrm{~g} / \mathrm{dL}$ ), 


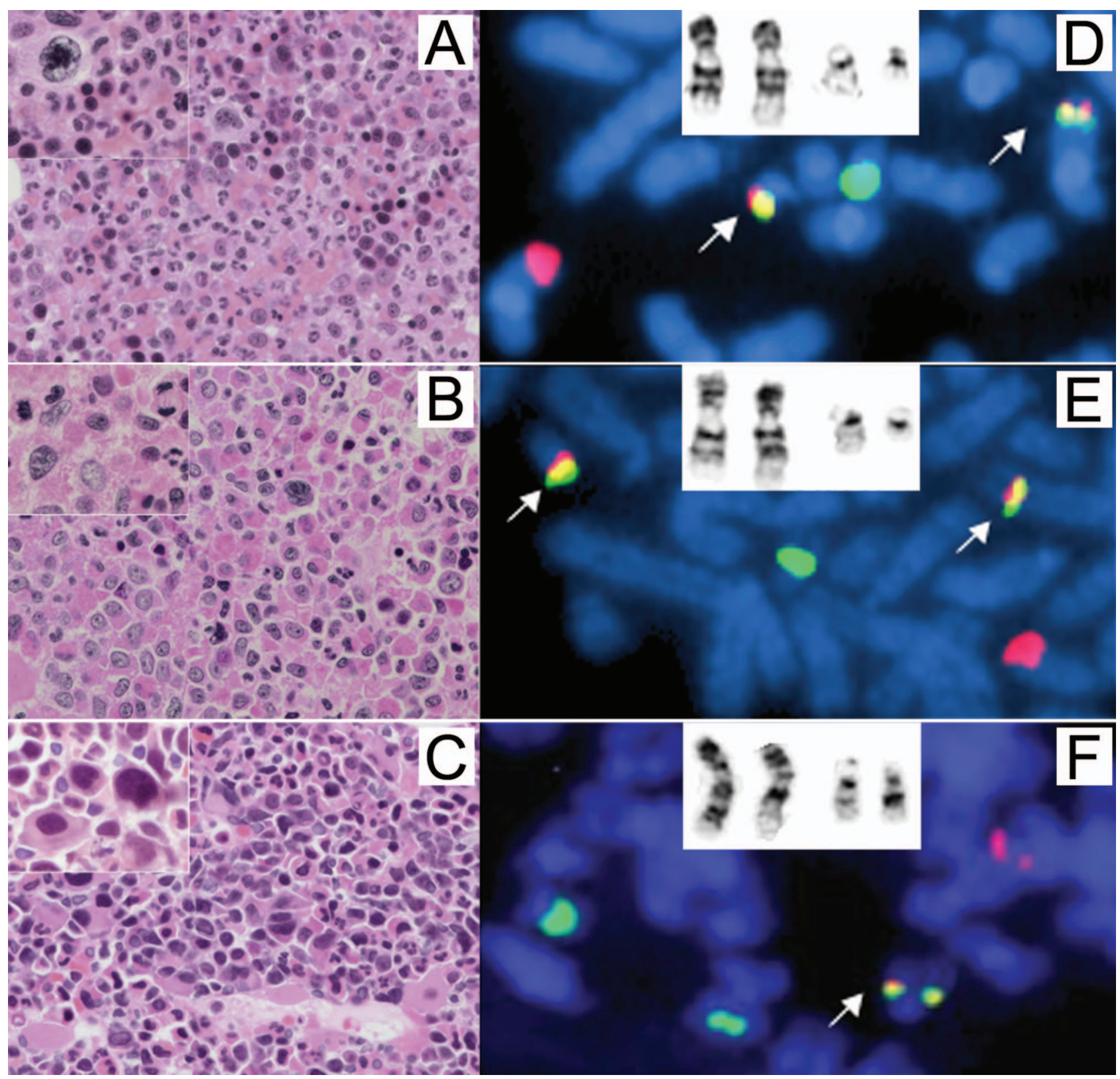

Figure 1. Microscopic and cytogenetic findings of cases 1 through 3 (case 1: panels A and D; case 2: panels B and E; case 3: panels C and F). Marked hypercellularity and florid myeloid hyperplasia are evident in panels A, B and C. Small and hypolobated megakaryocytes, characteristic of CML, are shown in insets A and C. A significant leftshift of myeloid maturation with increased immature myeloid precursors is evident in panel and inset B. H\&E stains, $200 \times$ magnification (insets $400 \times$ ). Partial Giemsa-banded karyotype (insets D-F) and FISH analysis using $\mathrm{bcr} / \mathrm{abl}$ dual fusion probe of CML cases (panels D-F). Arrows indicate fusion signals resulting from $\mathrm{t}(9 ; 22)$. Case 3 (panel and inset $\mathrm{F}$ ) is a variant translocation $\mathrm{t}(9 ; 22)(\mathrm{q} 22 ; \mathrm{q} 11.2)$ resulting in deletion on derivative 9 chromosome and 1 fused, 1 red, 2 green signal pattern compared to the usual 2 fused, 1 green, 1 red pattern in other cases.

and mild thrombocytopenia $\left(119 \times 10^{9} / \mathrm{L}\right)$. Serum chemistry evaluation was significant for a lactate dehydrogenase (LDH) level of $1998 \mathrm{U} / \mathrm{L}$ (reference range 115-221 U/L) and mildly increased aspartate amino transferase (AST, $56 \mathrm{U} / \mathrm{L}$, reference range 12 $38 \mathrm{U} / \mathrm{L})$.

Bone marrow examination showed hypercellularity (close to $100 \%$ ) with marked myeloid hyperplasia,
$10 \%$ myeloblasts and $8 \%$ basophils. Karyotypic analysis revealed a $\mathrm{t}(9 ; 22)(\mathrm{q} 34 ; \mathrm{q} 11.2)$ translocation in 20 out of 20 metaphases analysed and FISH identified a $B C R / A B L$ fusion signal in $91 \%$ of interphase nuclei (Figure 1). The diagnosis of CML was made, the prognostic Sokal index was 1.36 (high-risk), and the Hasford score was 2380.7 (high-risk). Treatment with imatinib $(400 \mathrm{mg} /$ day) 
was initiated and complete hematologic remission was achieved within 2 weeks.

The patient was started on erythropoietin treatment (40,000 U/week) 2 weeks after initiation of imatinib ( $\mathrm{Hb} 8.4 \mathrm{~g} / \mathrm{dL}$ ) and was admitted 6 weeks later with persistent anemia $(\mathrm{Hb} 4.9 \mathrm{~g} / \mathrm{dL}$, reticulocyte count $0.1 \%$ ). A bone marrow biopsy showed $100 \%$ cellularity with myeloid hyperplasia and markedly decreased erythroid progenitors. The erythropoietin dose was increased to $80,000 \mathrm{U} /$ week and imatinib was paused for 3 weeks. However, anemia persisted and 2 weeks after re-starting imatinib (300 mg/day) the HAART regimen was modified replacing abacavir/lamivudine/zidovudine with emtricitabine/tenofovir (to eliminate abacavir) and lopinavir/ritonavir with efavirenz (to eliminate ritonavir). In addition, imatinib was paused for 4 weeks and erythropoietin was discontinued. After these modifications, anemia gradually resolved over the ensuing 4 months. No follow-up bone marrow biopsy was performed.

FISH analysis of peripheral blood showed persistence of CML 7 months after diagnosis (fusion signal in $43.8 \%$ of cells), and complete cytogenetic remission was attained 13 months after diagnosis. Mean WBC, platelet count and $\mathrm{Hb}$ during 20 months of follow-up were $3.6 \times 10^{9} / \mathrm{L}, 131 \times 10^{9} / \mathrm{L}$ and 13.3 $\mathrm{g} / \mathrm{dL}$, respectively. Viral load remained undetectable $(<50$ copies $/ \mathrm{mL}$ ) and the most recent absolute CD4 cell count was 382 cells $/ \mu \mathrm{L}$.

\section{Patient 3}

A 61-year-old Hispanic male with an 11-year history of HIV-infection presented with hepatomegaly, thrombocytosis, anemia and a normal WBC. The patient had been receiving HAART for more than 10 years (most recently: nevirapine, abacavir, lamivudine) resulting in sustained virologic ( $<50$ copies/ $\mathrm{mL}$ ) and immunologic (CD4 count 523/ $\mathrm{L}$ ) response. His past medical history was significant for chronic renal insufficiency, coronary artery disease, hypertension, hypercholesterolemia and an adrenal tumor of unclear type that had been resected at an outside hospital 20 years prior.

A CBC revealed thrombocythemia $\left(>1000 \times 10^{9} /\right.$ $\mathrm{L})$, macrocytic anemia ( $\mathrm{Hb} 9.7 \mathrm{~g} / \mathrm{dL}, \mathrm{MCV} 128.5 \mathrm{fl}$, MCHC $33.1 \mathrm{~g} / \mathrm{dL})$, a normal WBC $(8600 / \mu \mathrm{L})$ and a differential count of $43 \%$ neutrophils, 3\% basophils, $3 \%$ metamyelocytes, 5\% atypical lymphocytes and $1 \%$ nucleated red blood cells. Serum chemistry evaluation was significant for hyperkalemia $(5.8 \mathrm{mM} / \mathrm{L}$, reference range 3.6-5.0), and elevated creatinine $1.8 \mathrm{mg} / \mathrm{dL}$.

Bone marrow examination showed hypercellularity (90\%) with myeloid and megakaryocytic hyperplasia and 9\% myeloblasts. Karyotypic analysis demon- strated a variant $\mathrm{t}(9 ; 22)$ ( $\mathrm{q} 22 ; \mathrm{q} 11.2)$ translocation in 20 of 20 metaphases and FISH revealed $B C R / A B L$ fusion genes in $83 \%$ of cells (Figure 1). The patient's prognostic Sokal index was 1.57 (high-risk) and the Hasford score was 1440.3 (intermediate-risk).

Imatinib treatment (400 $\mathrm{mg} /$ day) resulted in a partial hematologic remission with mean platelet count of $607 \times 10^{9} / \mathrm{L}$, WBC of $2000 / \mu \mathrm{L}$ and $\mathrm{Hb}$ of $7.9 \mathrm{~g} / \mathrm{dL}$ over the ensuing 4 months. He developed persistent anemia (nadir $6.9 \mathrm{~g} / \mathrm{dL}$ ), which required erythropoietin treatment, red blood cell transfusion and discontinuation of imatinib therapy. One month later, after improvement of the patient's anemia ( $\mathrm{Hb}$ $11.5 \mathrm{~g} / \mathrm{dL}$ ), imatinib was reinstituted at a dose of $200 \mathrm{mg}$ and gradually increased to $400 \mathrm{mg}$ over 16 months. Erythropoietin treatment was discontinued and the patient maintained a mean $\mathrm{Hb}$ of $12.8 \mathrm{~g} / \mathrm{dL}$, mean WBC of $4400 / \mu \mathrm{L}$ and mean platelet count of $159 \times 10^{9} / \mathrm{L}$ during the ensuing follow-up. Complete cytogenetic response was demonstrated by peripheral blood FISH analysis 17 months after diagnosis and maintained during the entire follow-up period. HIV viral load remained undetectable $(<50$ copies $/ \mathrm{mL}$ ) and the most recent CD4 cell count was $440 / \mu \mathrm{L}$.

\section{Discussion}

With long-term survival of $\mathrm{HIV}+$ patients in the era of HAART, non-HIV-associated hematologic malignancies are being encountered more frequently [816]. Six HIV+ patients with CML have previously been reported [17]. We describe three additional cases of HIV+ individuals who were diagnosed with CML at our institution between 2000 and 2006 (Table I). All three patients were males, received HAART at the time of diagnosis, and were older (mean: 60 years, range: 57-62 years) than previously reported patients (mean: 33 years, range: 9-48 years). Imatinib has recently been recommended by an international expert panel as first line treatment for early chronic phase $\mathrm{Ph}^{+} \mathrm{CML}$ and for patients who are not eligible for allogeneic hematopoietic cell transplantation [19]. However, scant information exists on treatment response to imatinib in HIV+ individuals.

All three patients in our series responded well to concurrent HAART and imatinib therapy. Cytogenetic response was achieved in all patients (complete in two). Long-term cytogenetic follow-up was available in two patients, both of whom maintained complete response over a period of 20-69 months. Patient 1 was not available for cytogenetic follow-up after having achieved a minor cytogenetic response at 3 months. All three patients maintained stable hemoglobin, leukocyte and platelet counts. 
Table I. Demographics, treatment, and follow-up of three HIV+ patients with CML.

\begin{tabular}{|c|c|c|c|c|c|c|c|c|c|}
\hline \multirow[b]{2}{*}{ Patient } & \multirow[b]{2}{*}{$\begin{array}{l}\text { Age }^{\star}, \text { sex } \\
\text { ethnicity }\end{array}$} & \multicolumn{3}{|c|}{ HIV } & \multicolumn{5}{|c|}{ CML } \\
\hline & & $\begin{array}{l}\text { Diagnosis [y], } \\
\text { complications }\end{array}$ & ART & $\mathrm{CD} 4, \mathrm{VL}$ & Presentation & $\begin{array}{l}\text { Cytogenetic } \\
\text { abnormality }\end{array}$ & $\begin{array}{l}\text { IM dose } \\
(\mathrm{mg})\end{array}$ & Outcome & $\begin{array}{l}\text { Follow-up } \\
{[\mathrm{mo}]}\end{array}$ \\
\hline 1 & $62, \mathrm{M}, \mathrm{C}$ & $\begin{array}{c}16 \\
\text { DLBCL, } \\
\text { thrush }\end{array}$ & $\begin{array}{l}\text { 3TC, ABC, } \\
\text { AZT, NVP }\end{array}$ & $488,<50$ & $\begin{array}{c}\text { Chronic } \\
\text { phase }\end{array}$ & $\mathrm{t}(9 ; 22)(\mathrm{q} 34 ; \mathrm{q} 11.2)$ & 600 & MCR & $3^{\star \star}$ \\
\hline 2 & 57, M, AA & $\begin{array}{c}16 \\
\text { Thrush, } \\
\text { PcP }\end{array}$ & $\begin{array}{l}\text { EFV, FTC, } \\
\text { TDF }\end{array}$ & $250,<50$ & $\begin{array}{l}\text { Accelerated } \\
\text { phase }\end{array}$ & $\mathrm{t}(9 ; 22)(\mathrm{q} 34 ; \mathrm{q} 11.2)$ & 400 & CCR & 20 \\
\hline 3 & $61, \mathrm{M}, \mathrm{H}$ & $\begin{array}{c}11 \\
-\end{array}$ & $\begin{array}{l}\text { 3TC, ABC, } \\
\text { NVP }\end{array}$ & $440,<50$ & $\begin{array}{c}\text { Chronic } \\
\text { phase }\end{array}$ & $\mathrm{t}(9 ; 22)(\mathrm{q} 22 ; \mathrm{q} 11.2)$ & 400 & CCR & 69 \\
\hline
\end{tabular}

${ }^{\star}$ Age and time since diagnosis of HIV-infection at time of CML diagnosis; antiretroviral regimen, $\mathrm{CD} 4^{+}$count (cells per $\mu \mathrm{L}$ ), viral load (copies $/ \mathrm{ml}$ ), and imatinib doses (mg per day) are the most current ones; time of follow-up is from diagnosis of CML. ${ }^{\star \star}$ No cytogenetic follow-up was available after three months; mean WBC, hemoglobin, and platelet counts over the next 19 months were normal.

Abbreviations: y, years; ART, antiretroviral treatment; VL, viral load; IM, imatinib; mo, months; C, Caucasian, DLBCL, diffuse large B-cell lymphoma; 3TC, lamivudine; ABC, abacavir; AZT, zidovudin; NVP, nevirapine; MCR, minor cytogenetic remission; AA, AfricanAmerican; PcP, Pneumocystis carinii (jiroveci) pneumonia; EFV, efavirenz; FTC, emtricitabine; TDF, tenofovir; CCR, complete cytogenetic remission.

Molecular response was not routinely monitored. Furthermore, the patients' HIV-infection remained well controlled since initiation of imatinib treatment. All three patients have sustained stable CD4 cell counts and suppression of viral replication.

Concurrent treatment for HIV-infection and CML was generally well tolerated. The course of two patients was initially complicated by anemia necessitating erythropoietin therapy and brief interruption of imatinib treatment. Imatinib is mainly metabolised by the cytochrome P450 (CYP) 3A4 isoenzyme and concurrent administration of numerous antiretroviral and antimicrobial drugs that inhibit CYP3A4 may lead to drug-drug interactions [20-22]. In the future, quantification of imatinib plasma concentrations by high-performance liquid chromatography or mass spectrometry might prove useful when suspecting toxicity or observing inadequate treatment response [23-25].

Bone marrow abnormalities are routinely observed in HIV+ individuals (dyspoiesis, denuded megakaryocyte nuclei) and lifetime exposure to AZT has been shown to result in myelodysplasia in an animal model $[18,26]$. However, there is no data indicating that HIV-infection or chronic antiretroviral therapy may increase the risk of myelodysplastic or myeloproliferative disorders in humans and the occurrence of CML in HIV+ patients is most likely coincidental.

Over the past decade, great progress has been made in the treatment of both CML and HIV. With current regimens, both conditions can be controlled through chronic therapy. It is encouraging for a growing number of affected patients that concurrent treatment of both CML and HIV is safe, effective, and can result in long-term survival.

\section{Acknowledgements}

The authors thank Dr. Robert N. Taub and Steven Palmer for providing clinical information.

\section{References}

1. Bonnet F, Lewden C, May T, Heripret L, Jougla E, Bevilacqua $S$, et al. Malignancy-related causes of death in human immunodeficiency virus-infected patients in the era of highly active antiretroviral therapy. Cancer 2004;101:317324.

2. Goedert JJ, Cote TR, Virgo P, Scoppa SM, Kingma DW, Gail $\mathrm{MH}$, et al. Spectrum of AIDS-associated malignant disorders. Lancet 1998;351:1833-1839.

3. Kravcik S, Hawley-Foss N, Victor G, Angel JB, Garber GE, Page S, et al. Causes of death of HIV-infected persons in Ottawa, Ontario, 1984-1995. Arch Intern Med 1997;157: 2069-2073.

4. Stein M, O'Sullivan P, Wachtel T, Fisher A, Mikolich D, Sepe S, et al. Causes of death in persons with human immunodeficiency virus infection. Am J Med 1992;93:387390.

5. Bower M, Palmieri C, Dhillon T. AIDS-related malignancies: changing epidemiology and the impact of highly active antiretroviral therapy. Curr Opin Infect Dis 2006;19:14-19.

6. Mocroft A, Brettle R, Kirk O, Blaxhult A, Parkin JM, Antunes $\mathrm{F}$, et al. Changes in the cause of death among HIV positive subjects across Europe: results from the EuroSIDA study. AIDS 2002;16:1663-1671.

7. Palella FJ Jr, Delaney KM, Moorman AC, Loveless MO, Fuhrer J, Satten GA, et al. Declining morbidity and mortality among patients with advanced human immunodeficiency virus infection. HIV Outpatient Study Investigators. N Engl J Med 1998;338:853-860.

8. Barbone E, Girolami A, Randi ML. HIV infection and polycythemia vera: a relationship worth pursuing? J Med 1993;24:409-410.

9. Drabick JJ, Magill AJ, Smith KJ, Nutman TB, Benson PM. Hypereosinophilic syndrome associated with HIV infection. Military Medical Consortium for Applied Retroviral Research. South Med J 1994;87:525-529. 
10. May LP, Kelly J, Sanchez M. Hypereosinophilic syndrome with unusual cutaneous manifestations in two men with HIV infection. J Am Acad Dermatol 1990;23:202-204.

11. Modest GA, Cooley TP, Zacks JF. HIV and refractory anemia with excess blasts (RAEB). Am J Hematol 2002;70: 318-319.

12. Ryu T, Ikeda $\mathrm{M}$, Okazaki Y, Tokuda $\mathrm{H}$, Yoshino $\mathrm{N}$, Honda $\mathrm{M}$, et al. Myelodysplasia associated with acquired immunodeficiency syndrome. Intern Med 2001;40:795-801.

13. Sassaki MG, Souza CA, Siciliano RF, Leite AG, Padilha SL. Polycythemia vera in a patient with the human immunodeficiency virus: a case report. Braz J Infect Dis 2000;4:204-207.

14. Serena M, Guido C, Emanuela B, Enrico G, Simona S, Daniela C, et al. First case of an AIDS patient with systemic mast cell disease associated with FIP1-positive eosinophilia treated with imatinib mesylate therapy. J Clin Oncol 2006;24:e6-e7.

15. Taha HM, Kaplan BH. Polycythemia vera in a patient with acquired immunodeficiency syndrome. Am J Hematol 1998;58:248-249.

16. van den Berg H, Scherpbier HJ, Kroes W. Myelodysplastic syndrome in an HIV-1-infected infant. Med Pediatr Oncol 1999;32:385.

17. Tsimberidou AM, Medina J, Cortes J, Rios A, Bonnie G, Faderl S, et al. Chronic myeloid leukemia in a patient with acquired immune deficiency syndrome: complete cytogenetic response with imatinib mesylate: report of a case and review of the literature. Leuk Res 2004;28:657-660.

18. Zucker-Franklin D, Termin CS, Cooper MC. Structural changes in the megakaryocytes of patients infected with the human immune deficiency virus (HIV-1). Am J Pathol 1989;134:1295-1303.
19. Baccarani M, Saglio G, Goldman J, Hochhaus A, Simonsson B, Appelbaum F, et al. Evolving concepts in the management of chronic myeloid leukemia: recommendations from an expert panel on behalf of the European LeukemiaNet. Blood 2006;108:1809-1820.

20. Peng B, Lloyd P, Schran H. Clinical pharmacokinetics of imatinib. Clin Pharmacokinet 2005;44:879-894.

21. Antoniou $T$, Tseng AL. Interactions between antiretrovirals and antineoplastic drug therapy. Clin Pharmacokinet 2005;44:111-145.

22. Burman W, Orr L. Carbamazepine toxicity after starting combination antiretroviral therapy including ritonavir and efavirenz. Aids 2000;14:2793-2794.

23. Oostendorp RL, Beijnen JH, Schellens JH, Tellingen O. Determination of imatinib mesylate and its main metabolite (CGP74588) in human plasma and murine specimens by ionpairing reversed-phase high-performance liquid chromatography. Biomed Chromatogr 2007;21:747-754.

24. Parise RA, Ramanathan RK, Hayes MJ, Egorin MJ. Liquid chromatographic-mass spectrometric assay for quantitation of imatinib and its main metabolite (CGP 74588) in plasma. J Chromatogr B Analyt Technol Biomed Life Sci 2003;791:3944.

25. Rochat B, Fayet A, Widmer N, Lahrichi SL, Pesse B, Decosterd LA, et al. Imatinib metabolite profiling in parallel to imatinib quantification in plasma of treated patients using liquid chromatography-mass spectrometry. J Mass Spectrom 2008; Feb 20 [epub].

26. Inoue $\mathrm{T}$, Cronkite EP, Hirabayashi $\mathrm{Y}$, Bullis JE Jr, Mitsui $\mathrm{H}$, Umemura $\mathrm{T}$. Lifetime treatment of mice with azidothymidine (AZT) produces myelodysplasia. Leukemia 1997;11 (Suppl 3):123-127. 